\title{
Identification, Purification, and Partial Characterization of an Organic Anion Binding Protein from Rat Liver Cell Plasma Membrane
}

\author{
allan W. Wolkoff and Cathie T. Chung, Department of Medicine and \\ Liver Research Center, Albert Einstein College of Medicine, \\ Bronx, New York 10461
}

A B S T R A C T Uptake of bilirubin, sulfobromophthalein (BSP), and other organic anions by the liver is a process with kinetics consistent with carrier mediation. The molecular basis of this transport mechanism is unknown. In the search for the putative organic anion carrier or receptor, the interaction of BSP with rat liver cell plasma membrane (LPM) has been studied. Specific binding of $\left[{ }^{35} \mathrm{~S}\right] \mathrm{BSP}$ to LPM was determined using a filtration assay. Results revealed high affinity $\left(K_{\mathrm{a}}\right.$ $\left.=0.27 \mu \mathrm{M}^{-1}\right)$, saturable $(6.3 \mathrm{nmol} / \mathrm{mg}$ protein $)$ binding, which was eliminated after preincubation with trypsin. Although $\left[{ }^{35}\right.$ S $]$ BSP was strongly bound to LPM, the binding was rapidly reversible, preventing direct identification and study of a specific binding site(s). To avoid this problem, a photoaffinity probe was devised, in which $\left[{ }^{35} \mathrm{~S}\right] \mathrm{BSP}$ is covalently bound to LPM after exposure to ultraviolet light. Subsequent sodium dodecyl sulfate gel electrophoresis and fluorography revealed radioactivity predominantly associated with a single 55,000 -mol wt protein. A protein with identical electrophoretic mobility was purified from deoxycholate solubilized LPM after affinity chromatography on glutathione-BSP-agarose gel. This protein migrated as a single band on sodium dodecyl sulfate gel electrophoresis and on urea gel isoelectric focusing. It contained $1-2$ residues of sialic acid per 55,000 -dalton protein, and was immunologically distinct from rat albumin and ligandin. It bound bilirubin with a $K_{\mathrm{d}}$ of $20 \mu \mathrm{M}$, as determined by tryptophan fluorescence quenching. Although the high affinity of this LPM protein for organic anions suggests that it may function as a hepatocellular organic anion receptor, its role in transport of these compounds is unknown.

\footnotetext{
A preliminary report of this work was presented at the 29th Annual Meeting of the American Association for the Study of Liver Disease, Chicago, Illinois and appeared in abstract form in 1978. Gastroenterology. 75: 995.

Received for publication 18 June 1979 and in revised form 14 January 1980.
}

\section{INTRODUCTION}

Bilirubin is formed in reticuloendothelial cells, released into the circulation where it binds to albumin with high affinity, and subsequently excreted almost entirely by the liver $(1,2)$. After intravenous administration, sulfobromophthalein $(\mathrm{BSP})^{1}$ also binds strongly to albumin (3) and is excreted predominantly by the liver (2). The hepatic uptake of bilirubin and BSP is rapid. After the intravenous injection of tracer amounts of $\left[{ }^{3} \mathrm{H}\right]$ bilirubin or $\left[{ }^{35} \mathrm{~S}\right] \mathrm{BSP}$ in rats, $\sim 40 \%$ of injected radioactivity is present within the liver 1.5 min later $(2,4-6)$. In the isolated perfused rat liver, $30-50 \%$ of an injected tracer bolus of $\left[{ }^{3} \mathrm{H}\right]$ bilirubin or $\left[{ }^{35} \mathrm{~S}\right] \mathrm{BSP}$ is removed in a single 40-s pass through the liver. If ${ }^{125}$ I-albumin is injected simultaneously, all ${ }^{125} \mathrm{I}$ is recovered in the hepatic vein effluent confirming that albumin does not accompany bilirubin or BSP into the liver cell $(7,8)$.

The hepatic uptake of bilirubin and BSP is saturable $(2,9)$ and these compounds demonstrate mutual competition for uptake (2). When rats were preloaded with bilirubin, the plasma disappearance of a subsequent tracer dose of $\left[{ }^{3} \mathrm{H}\right]$ bilirubin was enhanced $(2)$. Countertransport of BSP and bilirubin (i.e., efflux of previously taken up radiolabeled ligand from liver after subsequent infusion with unlabeled ligand) has also been described (2), although these phenomena could simply represent efflux of ligand from intracellular binding sites. Bile acids do not compete with bilirubin and BSP for hepatic uptake $(2,9)$.

Based on these results, a facilitated carrier-mediated membrane transport mechanism is postulated $(1,2,9)$ but its molecular basis is unknown. A role for ligandin, an abundant intrahepatocellular organic anion binding

\footnotetext{
${ }^{1}$ Abbreviations used in this paper: BSP, sulfobromophthalein; GSH, glutathione; LPM, liver cell plasma membrane; PBS, phosphate-buffered saline; SDS, sodium dodecyl sulfate.
} 
protein was postulated. However, hepatic ligandin concentration and the uptake rate constant for bilirubin did not correlate in studies of isolated perfused rat liver (7). The ligandin concentration correlated negatively with the efflux rate of bilirubin from liver into serum suggesting an intrahepatic sequestration or "storage" role for ligandin, rather than a direct role in transmembrane movement. Ligandin influences net hepatic uptake of organic anions by reducing their efflux from the hepatocyte after initial transfer from plasma into the cell (7).

The removal by the liver of other compounds including insulin (10), glucagon (11), and desialylated glycoproteins $(12,13)$ from plasma is dependent upon binding to specific plasma membrane receptors. The uptake of organic anions may also be mediated by a specific plasma membrane receptor. The binding of organic anions to purified liver cell plasma membrane (LPM) has been described (14-16), but its physiologic significance is unknown. In the present study, BSP binding to purified LPM is defined. Photoactivation of ${ }^{35}$ S]BSP after preincubation with LPM permitted identification of a membrane protein with which radioactivity was predominantly associated. This protein was purified to homogeneity by affinity chromatography on glutathione (GSH)-BSP-agarose and partially characterized.

\section{METHODS}

LP.M preparations. Male Sprague-Dawley rats (200-250 g) were obtained from Marland Farms (Peekskill, N. Y.) and fed ad libitum with Purina rat chow (Ralston Purina Co., St. Louis, Mo.). LPM was prepared from $\sim 100 \mathrm{~g}$ of liver by ratezonal ultracentrifugation according to the method of Wisher and Evans (17) in a Beckman Ti 15 rotor (Beckman Instruments Inc., Fullerton, Calif.). The resulting crude plasma membrane preparation was subfractionated on a discontinuous sucrose gradient (17). As described by Wisher and Evans (17), three subfractions were obtained at sucrose densities of 1.13 (zonal-light), 1.16 (zonal-heavy A), and 1.18 (zonal-heavy B). These were stored at $-80^{\circ} \mathrm{C}$ in $50 \mathrm{mM}$ Tris- $0.25 \mathrm{M}$ sucrose, at $\mathrm{pH} 7.6$ and used within $1 \mathrm{wk}$ of preparation. 5'nucleotidase (18), glucose-6-phosphatase (19), bilirubin glucuronoside glucuronosyl transferase $(20,21)$, succinate dehydrogenase (22), and $\beta$-glucuronidase (23) activities were determined in the subfractions and compared to results in homogenate. Protein concentration was determined by the method of Lowry et al. (24), using bovine serum albumin as the standard. The specific binding of insulin to membrane subfractions was determined as described by Evans et al. (25) using porcine insulin (25.5 U/mg, Schwarz/Mann Div., Becton, Dickinson \& Co., Orangeburg, N. J.). and ${ }^{125} \mathrm{I}$ monoiodinated porcine insulin $(100 \mu \mathrm{Ci} / \mu \mathrm{g}$, New England Nuclear, Boston, Mass.). The specific binding of glucagon to membrane subfractions was determined by the method of Desbouquois et al. (26) using unlabeled glucagon obtained from Schwarz/Mann Div., and ${ }^{125} \mathrm{I}$ monoiodinated glucagon $(151.8 \mu \mathrm{Ci} / \mu \mathrm{g})$ obtained from New England Nuclear.

Binding of $\left[{ }^{35} S\right] B S P$ to LPM. LPM $(20-50 \mu \mathrm{g}$ protein/ $20 \mu \mathrm{l})$ was incubated with $0.04-5.0 \mathrm{nmol}(0.09-11.4 \mu \mathrm{M})$ of ${ }^{35}$ S $] B S P$ (Amersham Corp., Arlington Heights, Ill. 40.3
$\mathrm{mCi} / \mathrm{mmol}$ ) in a polypropylene tube (Walter Sarstedt, Inc., Princeton, N. J.). The purity of $\left.{ }^{35} \mathrm{~S}\right] \mathrm{BSP}$ was $>95 \%$ as judged by thin-layer chromatography (27). Except where noted, the reaction was performed in $20 \mathrm{mM}$ phosphate buffer saline (PBS), pH 7.4, in a total volume of $0.44 \mathrm{ml}$. $1 \mathrm{~min}$ after incubation, $0.2 \mathrm{ml}$ was rapidly vacuum filtered on a Whatman $\mathrm{GF} / \mathrm{C}$ glass filter (Whatman Inc., Clifton, N. J.), which was quickly washed with $10 \mathrm{ml}$ of ice-cold buffer. The filter was placed in a glass scintillation vial, $10 \mathrm{ml}$ of Bray's solution (New England Nuclear) was added, and radioactivity was determined in an Intertechnique ABAC SL40 liquid scintillation counter (Intertechnique Instruments, Inc., Dover, N. J.) at a counting efficiency of $78 \%$. Recovery of a given amount of ${ }^{35} \mathrm{~S}$ was independent of the presence of a filter. The radioactivity of an unfiltered $0.2-\mathrm{ml}$ aliquot of incubation medium was also determined. Binding of BSP to the filter was studied using $0.2 \mathrm{ml}$ of $\left[{ }^{35} \mathrm{~S}\right]-$ BSP (0.05- $100 \mu \mathrm{M}$ in PBS, pH 7.4). The optimal time of incubation $(1-60 \mathrm{~min})$ temperature $\left(4-37^{\circ} \mathrm{C}\right), \mathrm{pH}$, and volume of filter wash $(5-20 \mathrm{ml})$ were determined. To insure that the filters did not allow significant quantities of LPM to pass through, 20-50 $\mu \mathrm{g}$ of LPM protein was applied to a filter that was washed with $10 \mathrm{ml}$ of PBS, pH 7.4. As a control, an identical aliquot of LPM was applied to another filter and placed directly into a test tube without washing. Protein content of both filters were determined and compared.

Nonspecific binding of ${ }^{[35}$ S]BSP to LPM was defined as radioactivity which bound in spite of a 1,000-fold dilution of specific activity with unlabeled BSP. To measure specific and nonspecific binding, $\left[{ }^{35} \mathrm{~S}\right] \mathrm{BSP}(0.09-11.4 \mu \mathrm{M})$ was incubated with LPM in the presence and absence of a 1,000-fold molar excess of unlabeled BSP $(0.09-11.4 \mathrm{mM})$. Radioactivity bound in the absence of excess unlabeled BSP was termed total binding, and radioactivity bound in the presence of excess unlabeled BSP was termed nonspecific binding. Specific binding represented the difference between total and nonspecific binding.

Binding of $\left[{ }^{35} \mathrm{~S}\right] \mathrm{BSP}$ to LPM was examined from the plot of $\bar{c} /$ milligram protein vs. [F] where $\bar{c}$ represents nmol of $\left[{ }^{35} \mathrm{~S}\right] \mathrm{BSP}$ bound per milligram of membrane protein and $[F]$ is the molar concentration of free or unbound ligand (28). Because nonlinearity of this plot of the data suggested more than one binding site, data were fit by computer using the least squares method of grids (29) to the equation representing two sets of binding sites with affinity constants $K_{\mathrm{a} 1}$ and $K_{\mathrm{a} 2}$ and capacity of $n_{1}$ and $n_{2}$, moles of ligand per milligram membrane protein, respectively:

$$
\bar{v}=\frac{\mathrm{n}_{1} K_{\mathrm{a} 1}[\mathrm{~F}]}{1+K_{\mathrm{a} 1}[\mathrm{~F}]}+\frac{\mathrm{n}_{2} K_{\mathrm{a} 2}[\mathrm{~F}]}{1+K_{\mathrm{a} 2}[\mathrm{~F}]}
$$

To study reversibility of binding, 0.1 or $1.2 \mathrm{nmol}$ of $\left.{ }^{[35} \mathrm{S}\right]-$ BSP were incubated with $75 \mu \mathrm{g}$ of LPM protein in a volume of $0.11 \mathrm{ml} .1 \mathrm{~min}$ later, $0.1 \mathrm{ml}$ was either filtered and washed, or added to $10 \mathrm{ml}$ of PBS, pH 7.4 with or without a 100 -fold molar excess of unlabeled BSP. At 1, 2, 5, and 10 min after dilution, the entire $10-\mathrm{ml}$ volume was rapidly filtered and washed with PBS, $\mathrm{pH} 7.4$, and LPM bound radioactivity was determined. The effect of preincubation with trypsin was determined by incubation of $10 \mu \mathrm{l}$ of a $2 \mathrm{mg} / \mathrm{ml}$ solution of trypsin (type III from bovine pancreas, Sigma Chemical Co., St. Louis, Mo.) in PBS, pH 7.4 with $0.2 \mathrm{ml}$ of LPM (2-3 mg protein $/ \mathrm{ml}$ ) for $30 \mathrm{~min}$ at $37^{\circ} \mathrm{C}$. Filter retention of LPM after trypsin pretreatment was determined by collecting the filtrate and wash of $300 \mu \mathrm{g}$ of LPM protein. This was lyophilized and protein concentration determined. Results were compared to that of an identical amount of LPM at $4^{\circ} \mathrm{C}$, to which an identical volume of trypsin was added immediately before filtration. The effect of preincubation with neuraminidase was 
determined by incubation of a $5 \mathrm{U} / \mathrm{ml}$ solution of Clostridium perfringens neuraminidase (type IX, Sigma Chemical Co.) in PBS, pH 7.4 with $0.2 \mathrm{ml}$ of LPM $(2-3 \mathrm{mg}$ protein $/ \mathrm{ml})$ for $30 \mathrm{~min}$ at $25^{\circ} \mathrm{C}$ (final neuraminidase concentration of 250 $\mathrm{mU} / \mathrm{ml}$ ). This concentration of neuraminidase was 50 -fold that necessary to inactivate by desialylation over $90 \%$ of the plasma membrane receptor for asialoglycoproteins when the same neuraminidase preparation was used. ${ }^{2}$ The effect of taurocholate (Sigma Chemical Co.) on $\left[{ }^{35}\right.$ S $]$ BSP binding to LPM was studied by incubating sodium taurocholate (final concentration $0.3 \mathrm{mM}$ ) with LPM and $\left[{ }^{35} \mathrm{~S}\right] \mathrm{BSP}$ in PBS, pH 7.4, and determining bound BSP. A control incubation lacking taurocholic acid was performed at the same time. Rat erythrocyte ghosts were prepared by the method of Dodge and Mitchell (30), and binding of $\left[{ }^{35} \mathrm{~S}\right] \mathrm{BSP}$ was studied in a manner identical to that used for study of LPM. Because GSH-BSP was used as an affinity adsorbent in affinity chromatography studies of LPM, competition of this compound with $\left.{ }^{35} \mathrm{~S}\right] \mathrm{BSP}$ for binding to LPM was examined. These studies were performed identically to the binding studies described above, except for inclusion of $22 \mu \mathrm{M}$ GSH-BSP in the incubation mixture.

Photoaffinity probe of BSP binding to LPM. Although BSP was strongly bound to LPM, the binding was rapidly reversible, which prevented direct identification and study of a specific binding site(s). To avoid this problem, a photoaffinity probe was devised, in which $\left.{ }^{35} \mathrm{~S}\right] \mathrm{BSP}$ is covalently bound to LPM after exposure to ultraviolet (UV) light. $0.2 \mathrm{ml}$ of each of the LPM subfractions $(2-3 \mathrm{mg}$ protein $/ \mathrm{ml}$ ), in $50 \mathrm{mM}$ Tris- $0.25 \mathrm{M}$ sucrose, $\mathrm{pH} 7.6$ was pipetted into a $5-\mathrm{ml}$ plastic beaker containing a stirring bar. This beaker was fit into a larger beaker containing ice and the two beakers were placed on a magnetic stirrer. $\left[{ }^{35} \mathrm{~S}\right] \mathrm{BSP}(0.5-1.0 \mathrm{nmol} / \mathrm{mg}$ protein) in $0.02 \mathrm{ml}$ was added and allowed to equilibrate for $1 \mathrm{~min}$. The mixture was irradiated from above with short wave (254 nm) UV light (Ultra-Violet Products, Inc., San Gabriel, Calif. model R-52, 1,300 W/cm ${ }^{2}$ at $15 \mathrm{~cm}$ ) for $3 \mathrm{~min}$. The same amount of $\left.{ }^{35} \mathrm{~S}\right] \mathrm{BSP}$ was again added, and the procedure repeated for an additional $3 \mathrm{~min}$. Sodium dodecyl sulfate (SDS) slab gel electrophoresis of the modified LPM was performed in $10 \%$ polyacrylamide (Bio-Rad Laboratories, Richmond Calif.) with a $3 \%$ spacer gel using Tris-glycine running buffer (31). SDS (Gallard-Schlesinger) was recrystallized from absolute ethanol (32). After electrophoresis, the gel was stained for 30 min with Coomassie Brilliant Blue $(0.2 \%)$, and destained with ethanol/acetic acid/water (5:7.5: 87.5). The gel was dehydrated in dimethyl sulfoxide and impregnated with 2,5-diphenyloxazole (New England Nuclear) before drying (33). Radioactivity was localized by fluorography using preflashed Kodak SB-54 film (34) (Eastman Kodak Co., Rochester, N. Y.).

GSH-BSP-agarose affinity chromatography of solubilized LPM. Identification of a specific LPM protein that bound photoactivated BSP suggested that this protein could be isolated by affinity chromatography. GSH-BSP was synthesized (35) and coupled to cyanogen bromide-activated agarose (Sepharose 4B) (31). The zonal-heavy A and zonal-heavy B LPM subfractions $(2-3 \mathrm{mg}$ protein $/ \mathrm{ml}$ ) were mixed with sodium deoxycholate $(0.4 \%$ final vol) and allowed to stand on ice for 30 min. After centrifugation for $20 \mathrm{~min}$ at $10,000 \mathrm{~g}$, the supernate was charged onto a $25 \mathrm{ml}$ GSH-BSP-agarose affinity column. The column was washed with $120 \mathrm{ml}$ of PBS, pH 7.4 and eluted with $0.01 \mathrm{M}$ Tris, $\mathrm{pH} 8.8\left(4^{\circ} \mathrm{C}\right)$. At this $\mathrm{pH}$, binding of $\left[{ }^{35} \mathrm{~S}\right] \mathrm{BSP}$ was reduced as compared to that at $\mathrm{pH}$ 7.4 (Fig. 2). Fractions were collected in 3-ml aliquots, and absorption at $280 \mathrm{~nm}$ indicated protein concentration. Protein-

${ }^{2}$ A. G. Morell and R. J. Stockert. Personal communication. containing fractions, which eluted at $\mathrm{pH} 8.8$, were combined. The solution was concentrated to a final volume of $5 \mathrm{ml}$ in an Amicon model 12 stirred cell with a PM 10 filter (Amicon Corp., Lexington, Mass.). The resulting protein solution was lyophilized and stored at $-80^{\circ} \mathrm{C}$.

The protein composition of the eluate was studied by SDS slab gel electrophoresis on a $10 \%$ polyacrylamide gel (31); less than $0.1 \mu \mathrm{g}$ of protein could easily be detected in a single band. Isoelectric focusing was performed in $6 \mathrm{M}$ urea (36). Sialic acid content was determined by the method of Warren (37). Amino acid analysis was performed after hydrolysis for $24 \mathrm{~h}$ in $6 \mathrm{~N} \mathrm{HCl}$ at $105^{\circ} \mathrm{C}$ using a Technicon TSM amino acid autoanalyzer (38) (Technicon Instruments Corp., Tarrytown, N. Y.). Immunodiffusion studies were performed in agar gel and reactivity of the concentrated protein $(0.1 \mathrm{ng} / \mathrm{ml})$ against monospecific antibodies to rat albumin and ligandin was tested (39). The isolated protein was iodinated by the chloramine $\mathrm{T}$ method (40), using $\mathrm{Na}^{125} \mathrm{I}$ obtained from New England Nuclear $(17 \mathrm{Ci} / \mathrm{mg})$. Distribution of radioactivity after SDS slab gel electrophoresis of the iodinated protein was determined by radioautography using Kodak XR-5 film and a polyester base high speed image intensification screen (Picker Corp., Cleveland, Ohio). In $4 \mathrm{~h}$ at $-70^{\circ} \mathrm{C},<1,000 \mathrm{cpm}$ of ${ }^{125} \mathrm{I}$ could easily be detected.

The binding of bilirubin to the isolated protein was determined by measuring the decrease in intrinsic fluorescence of protein upon addition of ligand $(4,41)$. A PerkinElmer fluorescence spectrometer MPF-3 (Perkin-Elmer Corp. Instrument Div., Norwalk, Conn.) with cuvettes of $0.5 \mathrm{ml}$ total volume was used. The cuvettes contained $0.6 \mu \mathrm{M}$ protein in $0.15 \mathrm{M}$ Tris, $\mathrm{pH} 8.2$, in $0.4 \mathrm{ml}$. The temperature was maintained at $25^{\circ} \mathrm{C}$. Bilirubin was dissolved in $0.05 \mathrm{~N}$ $\mathrm{NaOH}$ in a final concentration of $0.3 \mathrm{mM}$, and was immediately added to the cuvette in $0.002 \mathrm{ml}$ increments to generate fluorescence changes, which were measured at $330 \mathrm{~nm}$ after excitation at $285 \mathrm{~nm}$. The absorbance of bilirubin was sufficiently low that correction for inner filter effects (42) was unnecessary, and addition of diluent alone did not result in a decrement in fluorescence. Bilirubin did not fluoresce at the wavelengths studied. After correction for dilution, a reciprocal plot of change in fluorescence vs. bilirubin concentration was evaluated by least squares linear regression. Dissociation constants were calculated as the negative reciprocal of the $x$-intercept $(4,41)$. Because BSP absorbs light at $330 \mathrm{~nm}$, its binding could not be studied by this method.

\section{RESULTS}

LPM preparation. Recovery of protein and 5'-nucleotidase activity in the LPM preparation is seen in Table I. The zonal-light subfraction was enriched in 5'nucleotidase and bilirubin glucuronoside glucuronosyl transferase activities as compared to the zonal-heavy $A$ and heavy B subfractions. Specific activities of glucose-6phosphatase, $\beta$-glucuronidase, and succinate dehydrogenase were reduced as compared to specific activities in the homogenate (Table I). Specific binding of insulin and glucagon was 3-5 times higher in the zonal heavy subfractions than in the zonal-light subfraction (Fig. 1).

Binding of $\left.{ }^{35} \mathrm{~S}\right] B S P$ to $L P M$. In the absence of LPM,$<0.2 \%$ of $\left.{ }^{35} \mathrm{~S}\right] \mathrm{BSP}$ bound to the filters. In comparison to the amount of $\left.{ }^{35} \mathrm{~S}\right] \mathrm{BSP}$ bound in the presence of LPM, these counts were negligible, and were 
TABLE I

Protein Content and Marker Enzyme Activities in Liver Homogenate and LPM Subfractions

\begin{tabular}{|c|c|c|c|c|c|c|}
\hline & Protein & 5'nucleotidase & $\begin{array}{l}\text { Bilirubin } \\
\text { glucuronoside } \\
\text { glucuronosyl } \\
\text { transferase }\end{array}$ & $\begin{array}{l}\text { Glucose-6- } \\
\text { phosphatase }\end{array}$ & $\beta$-glucuronidase & $\begin{array}{c}\text { Succinate } \\
\text { dehydrogenase }\end{array}$ \\
\hline & mg/g liver & $\begin{array}{l}\text { pmol inorganic } \\
\text { phosphorous } \\
\text { released/mg } \\
\text { protein } / 20 \mathrm{~min}\end{array}$ & $\begin{array}{c}\text { nmol bilirubin } \\
\text { diglucuronide } \\
\text { formed/min/mg } \\
\text { protein }\end{array}$ & $\begin{array}{l}\text { umol inorganic } \\
\text { phosphorous } \\
\text { released/mg } \\
\text { protein } / 20 \mathrm{~min}\end{array}$ & $\begin{array}{l}\text { nmol phenolphthalein } \\
\text { glucuronide } \\
\text { hydrolyzed/mg } \\
\text { protein } 60 \mathrm{~min}\end{array}$ & $\begin{array}{c}\text { nmol succinate } \\
\text { reduced/mg } \\
\text { protein/min }\end{array}$ \\
\hline Homogenate & $184 \pm 7.9$ & $1.28 \pm 0.09(16)$ & $0.57 \pm 0.09(3)$ & $0.25 \pm 0.06(3)$ & $0.88(1)$ & $5.3(1)$ \\
\hline Zonal-light & $0.018 \pm 003 \quad(16)$ & $78.6 \pm 8.4(16)$ & $20.8 \pm 6.6(3)$ & $<0.006(3)$ & $0.36(1)$ & $<0.003(1)$ \\
\hline Zonal-heavy A & $0.060 \pm 0.012(16)$ & $8.9 \pm 1.2(16)$ & $12.2 \pm 6.4$ & $<0.005(3)$ & $0.08(1)$ & $<0.001(1)$ \\
\hline Zonal-heavy B & $0.080 \pm 0.011(16)$ & $4.2 \pm 0.7(16)$ & $5.7 \pm 2.7$ & $<0.004(3)$ & $0.08(1)$ & $<0.001(1)$ \\
\hline
\end{tabular}

not corrected for in later calculations. The filters retained over $95 \%$ of applied LPM protein. After pretreatment of LPM with trypsin, they retained over $90 \%$ of LPM protein. The association of $\left[{ }^{35} \mathrm{~S}\right] \mathrm{BSP}$ with LPM was rapid; maximal binding was attained by 1 min, which was used in subsequent studies. Washing the filter with $20 \mathrm{ml}$ of buffer did not remove more radioactivity than did a $10-\mathrm{ml}$ wash, and a $10-\mathrm{ml}$ wash was used in subsequent studies. Binding remained constant between $4^{\circ}$ and $37^{\circ} \mathrm{C}$, and there was no change in binding of $\left.{ }^{35} \mathrm{~S}\right] \mathrm{BSP}$ during the time that LPM was stored frozen. Binding of $\left[{ }^{35} \mathrm{~S}\right] \mathrm{BSP}$ was relatively constant between pH 6.5 and 8.0 (Fig. 2). Binding decreased above $\mathrm{pH}$ 7.4, and increased below $\mathrm{pH} 6.5$. Because of the unusual shape of this binding curve, an additional study was performed. Pretreatment of LPM with trypsin did not reduce binding of $\left.{ }^{35} \mathrm{~S}\right] \mathrm{BSP}$

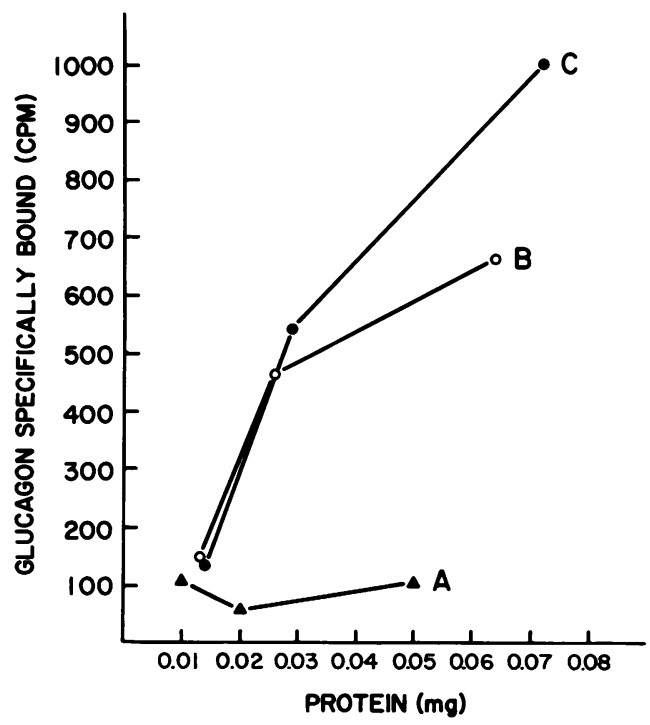

FIGURE 1 Specific binding of ${ }^{125}$ I-glucagon to the zonallight (A), zonal-heavy A (C), and zonal-heavy B (B) LPM subfractions. Experimental details are as in the text. as compared to intact LPM when studied at pH 3.5; at $\mathrm{pH} 7.4$, binding was reduced by $90 \%$. These different binding characteristics suggest differences in the mechanisms of ligand-LPM interaction at these $\mathrm{pH}$ values. It is possible that at low $\mathrm{pH}$, the now largely nonionized BSP molecule binds preferentially to membrane lipids. Subsequent studies were performed at the more physiologic $\mathrm{pH} 7.4$, in $20 \mathrm{mM}$ PBS.

Characteristics of $\left[{ }^{35} S\right] B S P$ binding to LPM. In the presence of 1,000-fold excess of unlabeled BSP, nonspecific binding of $\left.{ }^{35} \mathrm{~S}\right] \mathrm{BSP}$ to LPM was $<3 \%$ of total binding, and was not corrected for in subsequent studies. Binding of $\left.{ }^{[35} \mathrm{S}\right] \mathrm{BSP}$ to LPM was rapidly reversible upon dilution 100 -fold with buffer; $80 \%$ of LPM-bound $\left.{ }^{35} \mathrm{~S}\right] \mathrm{BSP}$ dissociated within $1 \mathrm{~min}$. No

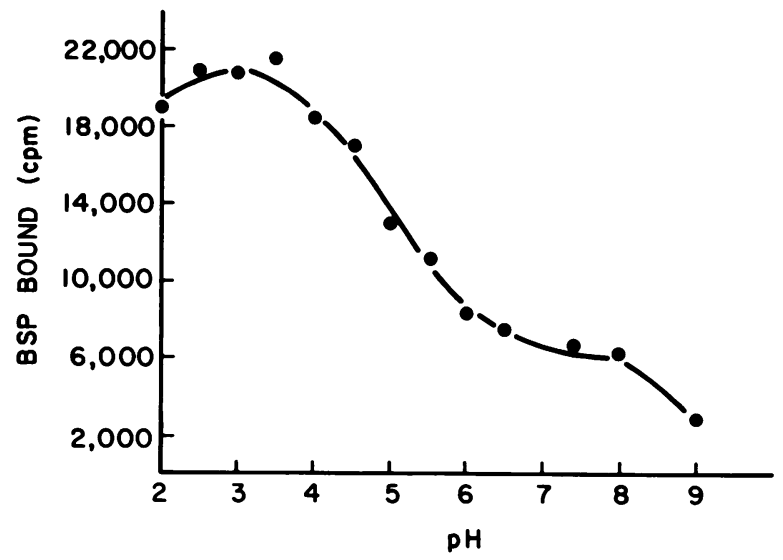

FIGURE 2 Effect of $\mathrm{pH}$ on binding of $\left.{ }^{35} \mathrm{~S}\right] \mathrm{BSP}$ to LPM. In this study, $61,000 \mathrm{cpm}(1.4 \mathrm{nmol})$ of $\left[{ }^{35} \mathrm{~S}\right] \mathrm{BSP}$ in $0.01 \mathrm{ml}$ was incubated with $0.02 \mathrm{ml}$ of zonal-heavy B LPM and $0.2 \mathrm{ml}$ of $0.15 \mathrm{M}$ sodium phosphate buffer at $\mathrm{pH} 2-9$; the final concentration of $\left.{ }^{35} \mathrm{~S}\right] \mathrm{BSP}$ was $6.2 \mu \mathrm{M}$. LPM bound radioactivity was determined as in the text. Pretreatment of LPM with trypsin did not reduce binding of $\left[{ }^{35} \mathrm{~S}\right] \mathrm{BSP}$ as compared to intact LPM when studied at $\mathrm{pH} 3.5$; at $\mathrm{pH} 7.4$, binding was reduced by $90 \%$. Similar results were obtained with the zonal-light and heavy A subfractions, using $\left[{ }^{35} \mathrm{~S}\right] \mathrm{BSP}$ concentrations as low as $0.3 \mu \mathrm{M}$. 
change in the rate of dissociation was seen when dilution was performed in the presence of a 100 -fold molar excess of unlabeled BSP (Fig. 3). This suggested that there was no significant negative cooperativity (43).

All three LPM subfractions bound $\left[{ }^{35}\right.$ S]BSP. Scatchard plots of the concentration of bound ligand per milligram membrane protein vs. the ratio of bound to free ligand per milligram membrane protein, were nonlinear. Because there was no evidence for negative cooperativity, this suggested high and low affinity binding sites (28). Computer analysis revealed that the light subfraction had a high affinity site, which bound ${ }^{35} \mathrm{~S}$ ]BSP with $K_{\mathrm{a} 1}$, of $0.54 \mu \mathrm{M}^{-1}$ and $\mathrm{n}_{1}$ of $2.6 \mathrm{nmol} / \mathrm{mg}$ protein, and a low affinity site with $K_{\mathrm{a} 2}=0.01 \mu \mathrm{M}^{-1}$ and $\mathrm{n}_{2}=27 \mathrm{nmol} / \mathrm{mg}$ protein. The heavy subfractions had $K_{\mathrm{a} 1}$, of $0.27 \mu \mathrm{M}^{-1}$ and $\mathrm{n}_{1}$ of $6.3 \mathrm{nmol} / \mathrm{mg}$ protein with $K_{\mathrm{a} 2}$ of $0.01 \mu \mathrm{M}^{-1}$ and $\mathrm{n}_{2}$ of $31 \mathrm{nmol} / \mathrm{mg}$ protein (Fig. 4). Preincubation of all three LPM subfractions with trypsin virtually eliminated binding (Fig. 5). Preincubation with neuraminidase had no effect on binding of $\left.{ }^{35} \mathrm{~S}\right] \mathrm{BSP}$ by LPM. Taurocholic acid in a concentration as high as $0.3 \mathrm{mM}$ had no effect on binding of ${ }^{35}$ S]BSP to LPM. GSH-BSP competitively inhibited binding of $\left[{ }^{35} \mathrm{~S}\right] \mathrm{BSP}$ to all three subfractions with an inhibition constant of $10 \mu \mathrm{M}$ for the high affinity binding site. Unlike the case for LPM, binding of [ $\left.{ }^{35} \mathrm{~S}\right]-$ BSP by rat erythrocyte ghosts generated a linear Scatchard plot, typical of a single class of binding sites. Analysis revealed $K_{\mathrm{a}}$ of $0.023 \mu \mathrm{M}^{-1}$ with $15.2 \mathrm{nmol}$ of $\left.{ }^{35} \mathrm{~S}\right] \mathrm{BSP}$ bound per milligram of protein. These results are

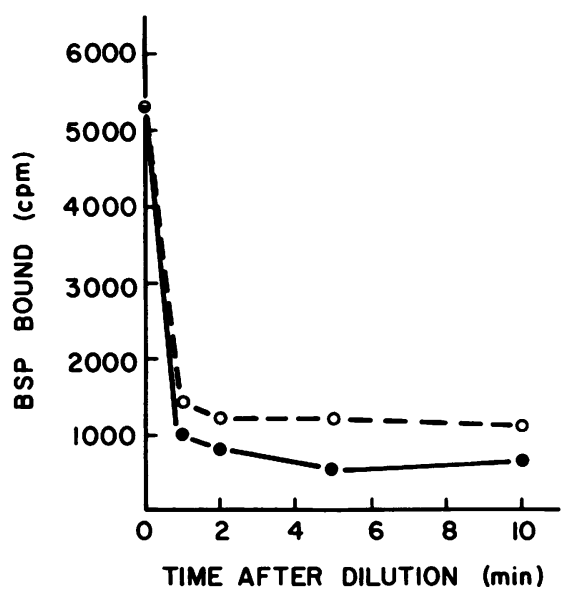

FIGURE 3 Reversibility of binding of $\left[{ }^{35}\right.$ S]BSP to LPM. Experimental details are as in the text. 1 min after incubation of $\left.{ }^{35} \mathrm{~S}\right] \mathrm{BSP}$ with LPM, $0.1 \mathrm{ml}$ of the mixture was either filtered and washed to determine bound BSP, or diluted 100fold with PBS $(O)$ or with PBS containing a 100-fold molar excess of unlabeled BSP (O). At intervals after dilution, the entire volume was filtered and bound radioactivity was quantitated. This experiment was performed with the zonalheavy B subfraction; similar results were obtained for the other two LPM subfractions.

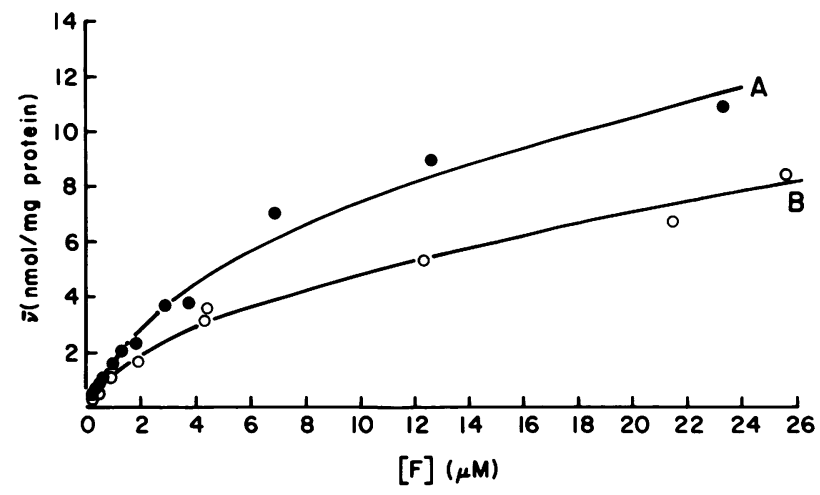

FIGURE 4 Plot of bound BSP $(\bar{v})$ vs. the concentration of free BSP $[F]$ as determined for the zonal-heavy B (A) and zonallight (B) subfractions. Results for the zonal-heavy A subfraction were identical to those for the zonal-heavy B subfraction. For each LPM subfraction, binding was analyzed, as in the text, to the equation representing two sets of binding sites with affinity constants $K_{\mathrm{a} 1}$ and $K_{\mathrm{a} 2}$, and capacity of $n_{1}$ and $\mathrm{n}_{2}$ nanomoles of ligand per milligram membrane protein. The lines represent least squares fits to the data. The zonal-light subfraction had $K_{\mathrm{a} 1}=0.54 \mu \mathrm{M}^{-1}, K_{\mathrm{a} 2}=0.01 \mu \mathrm{M}^{-1}, \mathrm{n}_{1}=2.6$ $\mathrm{nmol} / \mathrm{mg}$ protein, and $\mathrm{n}_{2}=27 \mathrm{nmol} / \mathrm{mg}$ protein. The zonal heavy subfractions had $K_{\mathrm{a} 1}=0.27 \mu \mathrm{M}^{-1}, K_{\mathrm{a} 2} 0.01 \mu \mathrm{M}^{-1}$, $\mathrm{n}_{1}=6.3 \mathrm{nmol} / \mathrm{mg}$ protein, and $\mathrm{n}_{2}=31 \mathrm{nmol} / \mathrm{mg}$ protein.

similar to binding of $\left[{ }^{35} \mathrm{~S}\right] \mathrm{BSP}$ by the low affinity binding site of LPM.

Photoaffinity probe of BSP binding to LPM. SDS gel electrophoresis of the two zonal-heavy subfractions revealed almost identical patterns, which differed from that of the zonal-light subfraction (Fig. 6). LPM from the zonal-heavy subfractions was incubated with $0.5 \mathrm{nmol}$ of $\left.{ }^{35} \mathrm{~S}\right] \mathrm{BSP} / \mathrm{mg}$ protein, irradiated with UV light, and SDS gel electrophoresis was performed. Fluorography of the gel revealed radioactivity predominantly associ-

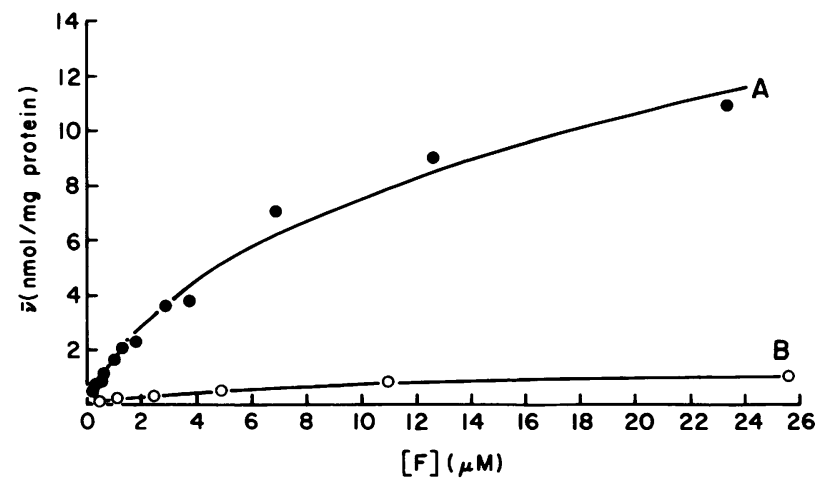

FIGURE 5 Effects of trypsin preincubation on LPM binding of $\left[{ }^{35} \mathrm{~S}\right] \mathrm{BSP}$. LPM was incubated for $30 \mathrm{~min}$ at $37^{\circ} \mathrm{C}$ with (B) and without (A) $100 \mu \mathrm{g} / \mathrm{ml}$ of trypsin. Binding of [ $\left.{ }^{35} \mathrm{~S}\right] \mathrm{BSP}$ to LPM was virtually eliminated following trypsin preincubation. Results in this illustration are for the zonal-heavy B subfraction, but were identical to results for the other two subfractions. 


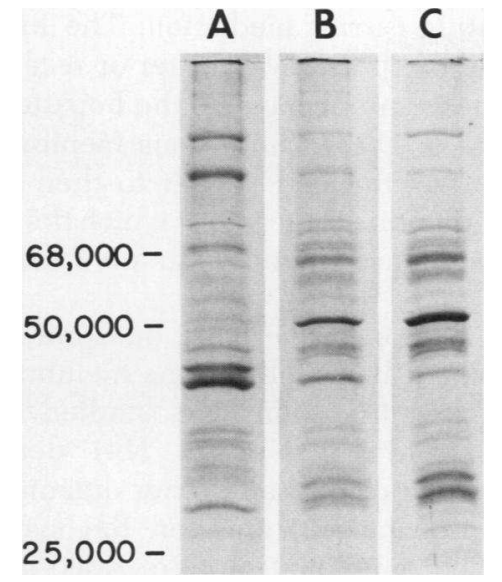

FiguRE 6 SDS polyacrylamide (10\%) slab gel electrophoresis of the zonal-light (A), zonal-heavy A (B), and zonal-heavy $B$ (C) LPM subfractions. Samples were solubilized in $0.4 \%$ SDS with $1 \% \beta$-mercaptoethanol, and $\sim 20 \mu \mathrm{g}$ of membrane protein was applied to the gel. Positions of bovine serum albumin $(68,000 \mathrm{~mol} \mathrm{wt})$ and gamma globulin subunits of 50,000 and $25,000 \mathrm{~mol} w \mathrm{wt}$ are indicated at the left.

ated with a single protein band of mol wt $\sim 55,000$ (Fig. 7 ). When the same procedure was performed without irradiation, no protein-associated radioactivity was detected. With larger amounts of $\left.{ }^{35} \mathrm{~S}\right] \mathrm{BSP}$, radioactivity was nonselectively associated with many proteins.

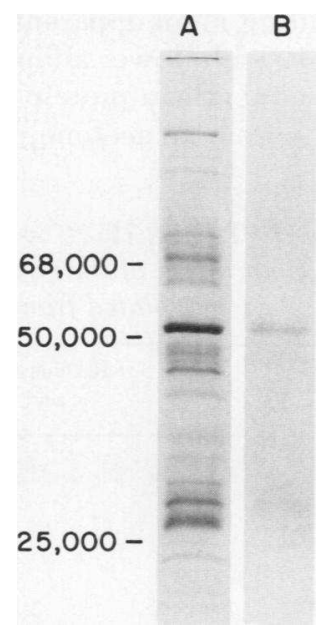

FIGURE 7 Photoaffinity probe of $\left[{ }^{35}\right.$ S $]$ BSP to LPM subfraction zonal-heavy B. A Coomassie Blue stained $10 \%$ polyacrylamide slab gel of this LPM subfraction is in column A. The adjacent lane contained LPM to which ${ }^{35}$ S]BSP had been attached as in the text; its fluorogram is in column B. Solubilization of samples and mol wt markers are as described in Fig. 6. Radioactivity is predominantly associated with a protein of $\sim 55,000 \mathrm{~mol}$ wt. Identical results were obtained with the zonal-heavy A subfraction. Similar study of the zonal-light subfraction revealed association of radioactivity with three protein bands of $20,000,23,000$, and 40,000 daltons, with no radioactivity in the $55,000-\mathrm{mol}$ wt region.
Fluorography of zonal-light LPM, which had been incubated with a similar amount of $\left.{ }^{35} \mathrm{~S}\right] \mathrm{BSP}$ and irradiated with UV light, revealed association of radioactivity with three protein bands $(20,000,23,000$, and 40,000 daltons $)$ with no single predominant band. There was no radioactivity in the 55,000-mol wt region.

Affinity chromatography of solubilized LPM. Over $90 \%$ of LPM protein was present in the supernate after solubilization of the zonal-heavy A or zonal-heavy B subfractions with $0.4 \%$ deoxycholate. Washing the column with PBS, pH 7.4, removed 70-80\% of applied protein. Elution with $10 \mathrm{mM}$ Tris, $\mathrm{pH} 8.8\left(4^{\circ} \mathrm{C}\right)$ removed a peak containing $1-2 \%$ of applied protein (Fig. 8). SDS gel electrophoresis of as much as $10 \mu \mathrm{g}$ of protein from this peak revealed a single protein band of 55,000 daltons (Fig. 9), which migrated in the same position as did radioactivity when fluorography was performed. After iodination of this protein with ${ }^{125} \mathrm{I}, \sim 100,000 \mathrm{cpm}$ were subjected to slab gel electrophoresis on $10 \%$ polyacrylamide. Radioautography of the gel revealed that all radioactivity was in a single band corresponding to a mol wt of 55,000 . Identical results were obtained when extracts of either of the two zonal-heavy subfractionations were chromatographed. Because of a relatively poor yield on subfractionation of LPM, studies of affinity chromatography of the zonal-light subfraction have not, as yet, been performed.

Isoelectric focusing of up to $5 \mu \mathrm{g}$ of the purified protein was performed in $6 \mathrm{M}$ urea. Without urea, the protein precipitated at the top of the gel and did not enter. After staining with Coomassie Brilliant Blue, a single protein band was found (Fig. 10). Amino acid analysis revealed a relative enrichment in phenylalanine and acidic residues (Table II). There were 1-2

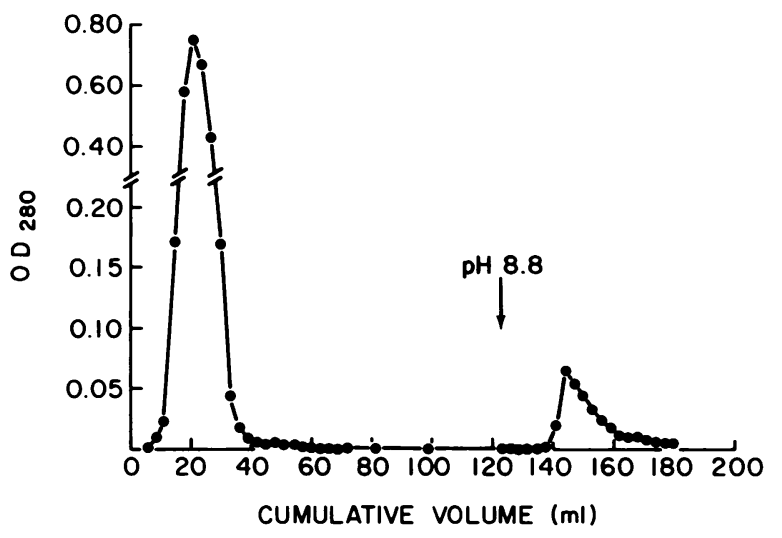

FIGURE 8 Affinity chromatography of deoxycholate solubilized LPM on GSH-BSP-agarose gel. LPM was solubilized in $0.4 \%$ deoxycholate, centrifuged for $20 \mathrm{~min}$ at $10,000 \mathrm{~g}$, and the supernate was charged onto a $25 \mathrm{ml}$ GSH-BSP-agarose gel affinity column. The column was washed with $120 \mathrm{ml}$ of PBS, pH 7.4 and eluted with $0.01 \mathrm{M}$ Tris, pH $8.8\left(4^{\circ} \mathrm{C}\right)$. Absorption at $280 \mathrm{~nm}$ indicated protein concentration. 


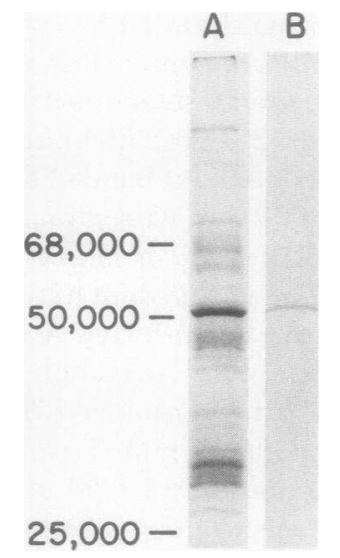

FIGURE 9 SDS polyacrylamide (10\%) slab gel electrophoresis patterns of approximately $25 \mu \mathrm{g}$ of the zonal-heavy B LPM subfraction (A) and $5 \mu \mathrm{g}$ of the isolated organic anion binding protein (B) after staining with Coomassie Blue. Solubilization of samples and molecular weight markers are as in Fig. 6. The isolated protein migrates as a single band of $\sim 55,000$ mol wt. Identical results were obtained for the zonal-heavy A subfraction.

residues of sialic acid/55,000-dalton protein. Diffusion of purified protein against monospecific antibody to rat albumin and rat ligandin revealed no immunoreactivity. Studies of the binding of bilirubin to the isolated protein revealed a dissociation constant of $20 \mu \mathrm{M}$ (Fig. 11).

\section{DISCUSSION}

The uptake of bilirubin, BSP, and other organic anions by the liver is rapid and has kinetic character-

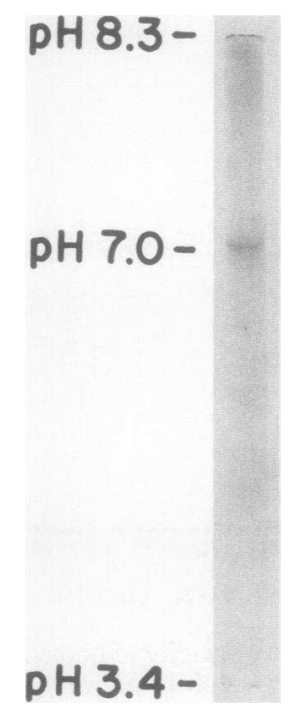

FIGURE 10 Isoelectric focusing gel of $\sim 3 \mu \mathrm{g}$ of the isolated organic anion binding protein after staining with Coomassie Blue. This procedure was performed in $6 \mathrm{M}$ urea and reveals a single protein band of isoelectric point 7 . istics suggesting carrier mediation. The biochemical mechanism of the presumed carrier or receptor is unknown. As these anions traverse the hepatic sinusoids into the space of Disse, the plasma membrane of the hepatocyte offers the first barrier to their entry into the cell. Whether this is the site at which the specificity and carrier-mediated kinetics of anion uptake occur is not known.

In an attempt to answer this question, the interaction of isolated liver cell plasma membrane preparations with organic anions was studied by several investigators. Cornelius et al. (14) demonstrated saturable binding of BSP and other organic anions to a rat LPM preparation; however, the magnitude of binding $(\sim 200 \mathrm{nmol} / \mathrm{mg}$ protein) was larger than expected for a physiologic process. Bilirubin competes for uptake of BSP by the liver in vivo, but had no effect on binding in vitro. Reichen et al. (16) determined $K_{\mathrm{d}}$ of BSP binding to LPM as 390-650 $\mu \mathrm{M}$, with saturation at $230-440 \mathrm{nmol} / \mathrm{mg}$ protein. Although results of these two studies are in agreement, the number of binding sites is high, and the affinity of BSP for LPM is lower by two orders of magnitude than is the affinity of BSP for albumin (3), from which it is extracted before entering the hepatocyte. Tiribelli et al. (15) studied BSP binding to rat LPM by continuous flow dialysis. High affinity binding of BSP was described with $K_{\mathrm{d}}$ of $4.88 \mu \mathrm{M}$ and saturation at $40.4 \mathrm{nmol} \mathrm{BSP} / \mathrm{mg}$ protein. Bilirubin $(0.5 \mathrm{mM})$ competitively inhibited BSP binding, resulting in an apparent $K_{\mathrm{d}}$ of $10.5 \mu \mathrm{M}$, which indicates $\sim 100$-fold lower affinity of membrane for bilirubin. Subsequently, a protein was isolated by gel chromatography from an acetone powder of crude

TABLE II

Amino Acid Composition of the Organic Anion Binding Protein Isolated from LPM

\begin{tabular}{lc}
\hline \multicolumn{1}{c}{ Amino acid } & $\begin{array}{c}\text { Residues/l,000 amino } \\
\text { acid residues }\end{array}$ \\
\hline Aspartic acid & 86 \\
Methionine & 14 \\
Threonine & 53 \\
Serine & 64 \\
Glutamic acid & 124 \\
Proline & 59 \\
Glycine & 96 \\
Alanine & 88 \\
Valine & 69 \\
Isoleucine & 58 \\
Leucine & 93 \\
Tyrosine & 17 \\
Phenylalanine & 40 \\
Lysine & 63 \\
Histidine & 26 \\
Arginine & 49 \\
\hline
\end{tabular}




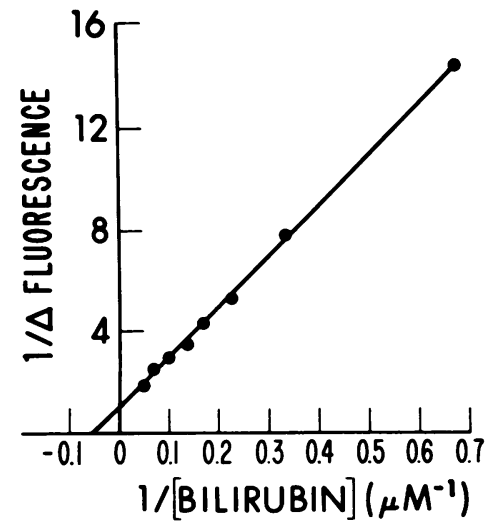

FIGURE 11 Binding of bilirubin to the isolated organic anion binding protein. Details are as in the text. A double reciprocal plot of the decrement in fluorescence of the protein vs. the concentration of added ligand is shown. The dissociation constant $(20 \mu \mathrm{M})$ is calculated as the negative reciprocal of the $x$-intercept.

LPM (44). This 170,000-dalton protein binds over 100 nmol of BSP per mg, implying at least 17 binding sites for BSP; $K_{d}$ was $4 \mu \mathrm{M}$. Whether the large number of binding sites indicates unusual binding kinetics or is an artifact of the methodology is not clear.

In the present study of BSP binding to LPM subfractions, high and low affinity binding sites were detected. $K_{\mathrm{a}}$ of the high affinity site is close to that described by Tiribelli et al. differs from results in the two previous studies and is similar to $K_{\mathrm{a}}$ of BSP for rat serum albumin (3) or rat ligandin (45). The strong affinity of BSP for LPM suggests that this binding may represent a physiologic process.

The virtual elimination of BSP binding to zonalheavy and light LPM after preincubation with trypsin suggests that BSP interacts with a LPM protein(s). To identify the BSP binding site, $\left[{ }^{35} \mathrm{~S}\right] \mathrm{BSP}$ was photoactivated after preincubation with LPM. In studies of zonal-heavy LPM, when $\left[{ }^{35}\right.$ S]BSP was present in low concentration, radioactivity was associated predominantly with a single 55,000 -mol wt protein after SDS gel electrophoresis of the zonal-heavy A or B subfractions. Other proteins were accessible to $\left.{ }^{35} \mathrm{~S}\right] \mathrm{BSP}$ as demonstrated by the fact that irradiation of LPM after preincubation with a high concentration of $\left[{ }^{35} \mathrm{~S}\right]-$ BSP resulted in association of radioactivity with many proteins. A similar study performed using the zonallight subfraction revealed binding to three protein bands $(20,000,23,000$, and 40,000 daltons) with no single predominant band of radioactivity and no radioactivity in the 55,000 -mol wt region. Whether these bands represent distinct proteins or are components of a single protein is not known, and the high affinity binding site for BSP may be on either or all of these proteins. These photoaffinity studies suggest that the similar binding kinetics of $\left.{ }^{35} \mathrm{~S}\right] \mathrm{BSP}$ to zonal-heavy and light LPM may be due to binding of ligand to different proteins of comparable affinities. Wisher and Evans (17) suggest that the two heavy subfractions are derived from the sinusoidal and contiguous faces of the hepatocyte, whereas the light subfraction is derived from the canalicular aspect. If this localization of subfractions is correct, the 55,000 -mol wt binding protein would be in the anticipated position to function in hepatic uptake of organic anions. To purify this protein, affinity chromatography of deoxycholate solubilized LPM was performed on GSH-BSP-agarose gel. Purification was demonstrated by migration of the protein as a single $55,000-\mathrm{mol}$ wt band after SDS gel electrophoresis.

Results of biochemical and electron microscopic studies suggest that the organic anion binding protein is a component of liver cell plasma membranes. Because is is uncertain whether any biochemical markers are specific for only one surface of the hepatocyte, the sinusoidal localization of these two zonalheavy subfractions is tentative. Biochemical studies (Table I) reveal that they are enriched in the plasma membrane markers 5'nucleotidase and bilirubin glucuronoside glucuronosyl transferase, as compared to homogenates. Activities of glucose-6-phosphatase (endoplasmic reticulum), $\beta$-glucuronidase (lysosomes), and succinate dehydrogenase (mitochondria) are $<10 \%$ of that in homogenate. Mr. Jonathan Rothblatt, in Dr. Alex B. Novikoff's laboratory (Albert Einstein College of Medicine, Bronx, N. Y.), examined a pelleted aliquot of the zonal-heavy $\mathrm{A}$ subfraction through its entire depth, at a magnification of 1,300 , and random areas were viewed at 10,000 . No nuclei, mitochondria, rough endoplasmic reticulum or other recognizable organelles contaminated the fraction, save for a single residual body. The origin of the membranes could not be established, but recognizable bile canalicular fronts were not seen.

BSP adsorbs light at $330 \mathrm{~nm}$ and binding to the isolated protein could not be determined by the tryptophan fluorescence quenching method. Because the isolated protein precipitates and binds to dialysis tubing, equilibrium dialysis could not be used to study BSP binding. By contrast, bilirubin bound to the isolated protein with high affinity. Although the fluorography experiments indicate that the protein binds $\left.{ }^{35} \mathrm{~S}\right] \mathrm{BSP}$ in isolated LPM, its potential role in vivo is speculative. Its role as a liver cell plasma membrane receptor for organic anions, and relationship to the intracellular transport of these compounds is unknown. Identification of animal models in which the hepatic uptake of organic anions is reduced, such as mutant Southdown sheep and fetal or neonatal animals, may elucidate the relationship of this putative receptor to hepatic transport. 


\section{ACKNOWLEDGMENTS}

The authors are thankful to Dr. J. Roy Chowdhury of the Liver Research Center, Albert Einstein College of Medicine, Bronx, ‥ Y., for performing assays of bilirubin glucuronoside glucuronosyl transferase.

This work was supported by National Institutes of Health grants A.M17702, A.M23026, and A.M02019.

\section{REFERENCES}

1. Berk, P. D., A. W. Wolkoff, and X. I. Berlin. 1975. Inborn errors of bilirubin metabolism. Med. Clin. N. Am. 59: 80)3-816.

2. Scharschmidt, B. F., J. G. Waggoner, and P. D. Berk. 1975. Hepatic organic anion uptake in the rat. J. Clin. Invest. 56: 1280-1292.

3. Kamisaka, K., I. Listowsky, J. J. Betheil, and I. M. Arias. 1974. Competitive binding of bilirubin, sulfobromophthalein, indocyanine green and other organic anions to human and bovine serum albumin. Biochim. Biophys. Acta. 365: 169-180.

4. Wolkoff, A. W., J. N. Ketley, J. G. Waggoner, P. D. Berk, and W. B. Jakoby. 1978. Hepatic accumulation and intracellular binding of conjugated bilirubin. J. Clin. Invest. 61: $142-149$.

5. Brown, W. R., G. M. Grodsky, and J. V. Carbone. 1964. Intracellular distribution of tritiated bilirubin during hepatic uptake and excretion. Am. J. Physiol. 207: 12371241 .

6. Bernstein, L. H., J. Ben-Ezzer, L. Gartner, and I. M. Arias. 1966. Hepatic intracellular distribution of tritiumlabeled unconjugated and conjugated bilirubin in normal and Gunn rats. J. Clin. Invest. 45: 1194-1201.

7. Wolkoff, A. W., C. A. Goresky, J. Sellin, Z. Gatmaitan, and I. M. Arias. 1979. The role of ligandin in the transfer of bilirubin from plasma into the liver. Am. J. Physiol. 236: E638-E648.

8. Goresky, C. A. 1964. Initial distribution and rate of uptake of sulfobromophthalein in the liver. Am.J. Physiol. 207: 13-26.

9. Paumgartner, G., and J. Reichen. 1976. Kinetics of hepatic uptake of unconjugated bilirubin. Clin. Sci. Mol. Med. 51: $169-176$.

10. Cuatrecasas, P. 1973. Insulin receptor of liver and fat cell membranes. Fed. Proc. 32: 1838-1846.

11. Pohl, S. L., L. Birnbaumer, and M. Rodbell. The glucagon-sensitive adenyl cyclase system in plasma membranes of rat liver. J. Biol. Chem. 246: 1849-1856.

12. Hudgin, R. L., W. E. Pricer, Jr., G. Ashwell, R. J. Stockert, and A. G. Morell. 1974. The isolation and properties of a rabbit liver binding protein specific for asialoglycoproteins. J. Biol. Chem. 249: 5536-5543.

13. Regoeczi, E., M. T. Debanne, M. W. C. Hatton, and A. Koj. 1978. Elimination of asialofetuin and asialoorosomucoid by the intact rat. Quantitative aspects of the hepatic clearance mechanism. Biochim. Biophys. Acta. 541: $372-384$.

14. Cornelius, C. E., J. Ben-Ezzer, and I. M. Arias. 1967. Binding of sulfobromophthalein sodium (BSP) and other organic anions by isolated hepatic cell plasma membranes in vitro. Proc. Soc. Exp. Biol. Med. 124: 665-667.

15. Tiribelli, C., E. Panfili, G. Sandri, M. Frezza, and G. L. Sottocasa. 1976. Liver bromsulphonphthalein transport as a carrier mediated process. In Diseases of the Liver and Biliary Tract. C. M. Leevy, editor. S. Karger A. G., Basel, Switzerland. 55-59.

16. Reichen, J., B. L. Blitzer, and P. D. Berk. 1976. The binding of anionic dyes to hepatocellular plasma membranes. Clin. Res. 25: 468. (Abstr.)

17. Wisher, .1. H., and W. H. Evans. 1975. Functional polarity of the rat hepatocyte plasma membrane. Isolation and characterization of plasma membrane subfractions from the blood-sinusoidal, bile-canalicular and contiguous surfaces of the hepatocyte. Biochem. J. 146: $375-388$.

18. Touster, O., N. N. Aronson Jr., J. T. Dulaney, and H. Hendrickson. 1970. Isolation of rat liver plasma membranes. Use of nucleotide phosphatase and phosphodiesterase-I as marker enzymes. J. Cell Biol. 47: 604-618.

19. Swanson, M. A. 1950. Phosphatases of Liver. I. Glucose6-phosphatase. J. Biol. Chem. 184: 647-659.

20. Jansen, P. L. M., J. R. Chowdhury, E. B. Fischberg. and I. M. Arias. 1977. Enzymatic conversion of bilirubin monoglucuronide to diglucuronide by rat liver plasma membranes. J. Biol. Chem. 252: 2710-2716.

21. Chowdhury, J. R., P. L. M. Jansen, E. B. Fischberg, A. Daniller, and I. M. Arias. 1978. Hepatic conversion of bilirubin monoglucuronide to diglucuronide in uridine diphosphate-glucuronyl transferase-deficient man and rat by bilirubin glucuronoside glucuronosyltransferase. $J$. Clin. Invest. 62: 191-196.

22. Earl, D. C. N., and A. Korner. 1965. The isblation and properties of cardiac ribosomes and polysomes. Biochem. J. 94: $721-734$.

23. Levvy, G. A., and C. A. Marsh. 1959. Preparation and properties of B-glucuronidase. Adv. Carbohydr. Chem. 14: $381-428$.

24. Lowry, O. H., N. J. Rosebrough, A. L. Farr, and R. J. Randall. 1951. Protein measurement with Folin phenolreagent. J. Biol. Chem. 193: 265-275.

25. Evans, W. H., J. J. M. Bergeron, and I. I. Geschwind. 1973. Distribution of insulin receptor sites among liver plasma membrane subfractions. FEBS (Fed. Eur. Biochem. Soc.) Lett. 34: 259-262.

26. Desbuquois, B., F. Krug, and P. Cuatrecasas. 1974. Inhibitors of glucagon inactivation. Effect of glucagonreceptor interactions and glucagon-stimulated adenylate cyclase activity in liver cell membranes. Biochim. Biophys. Acta. 343: 101-120.

27. Dhumeaux, D., and P. Berthelot. 1975. Chronic hyperbilirubinemia associated with hepatic uptake and storage impairment. Gastroenterology. 69: 988-993.

28. Westphal, U. 1969. Assay and properties of corticosteroid-binding globulin and other steroid-binding serum proteins. Methods Enzymol. 15: 761-796.

29. Bevington, P. R. 1969. Data Reduction and Error Analysis for the Physical Sciences. McGraw-Hill, New York.

30. Dodge, J. T., C. Mitchell, and D. J. Hanahan. 1963. The preparation and chemical characteristics of hemoglobin-free ghosts of human erythrocytes. Arch. Biochem. Biophys. 100: 119-130.

31. Wolkoff, A. W., M. M. Bhargava, C. Chung, and Z. Gatmaitan. 1979. Purification of ligandin by affinity chromatography on sulfobromophthalein-agarose gel. Proc. Soc. Exp. Biol. Med. 160: 150-153.

32. Maizel, J. V., Jr. 1971. Polyacrylamide gel electrophoresis of viral proteins. Methods Virol. 5: 179-246.

3.3. Bonner, W. M., and R. A. Laskey. 1974. A film detection method for tritium-labeled proteins and nucleic acids in polyacrylamide gels. Eur.J. Biochem. 46: 83-88.

34. Laskey, R. A., and A. D. Mills. 1975. Quantitative film detection of ${ }^{3} \mathrm{H}$ and ${ }^{14} \mathrm{C}$ in polyacrylamide gels by fluorography. Eur. J. Biochem. 56: 33.5-341.

35. Whelan, G., J. Hoch, and B. Combes. 1970. A direct assessment of the importance of conjugation for biliary 
transport of sulfobromophthalein sodium. J. Lab. Clin. Med. 75: 542-557.

36. O'Farrell, P. H. 1975. High resolution two-dimensional electrophoresis of proteins.J. Biol. Chem. 250: 4007-4021.

37. Warren, L. 1959. The thiobarbituric acid assay of sialic acids. J. Biol. Chem. 234: 1971-1975.

38. Ertengshausen, G., and H. J. Adler. 1969. A new accelerated fully automated system for amino acid analysis by ion-exchange chromatography.J. Chromatogr. 44: 620-623.

39. Fleischner, G., J. Robbins, and I. M. Arias. 1972. Immunological studies of $Y$ protein. A major cytoplasmic organic anion-binding protein in rat liver. J. Clin. Invest. 51: 677-684.

40. Greenwood, F. C., W. M. Hunter, and J. S. Glover. 1963. The preparation of ${ }^{131}$ I-labelled human growth hormone of high specific radioactivity. Biochem. J. 89: $114-123$.
41. Ketley, J. N., W. H. Habig, and W. B. Jakoby. 1975. Binding of nonsubstrate ligands to the glutathione transferases. J. Biol. Chem. 250: 8670-8673.

42. Brand, L., and A. Witholt. 1967. Fluorescence measurements. Methods Enzymol. 11: 776-856.

43. DeMeyts, P., J. Roth, D. M. Neville, Jr., J. G. Gavin, III, and M. A. Lesniak. Insulin interactions with its receptors: experimental evidence for negative cooperativity. 1973. Biochem. Biophys. Res. Commun. 55: 154-161. 1973.

44. Tiribelli, C., G. Lunazzi, M. Luciani, E. Panfili, B. Gassin, G. Liut, G. Sandri, and G. Sottocasa. 1978. Isolation of a sulfobromophthalein-binding protein from hepatocyte plasma membrane. Biochim. Biophys. Acta. 532: $105-112$.

45. Kamisaka, K., I. Listowsky, Z. Gatmaitan, and I. M. Arias. 1975. Interactions of bilirubin and other ligands with ligandin. Biochemistry. 14: 2175-2180. 